\title{
Erratum to: Heller myotomy and intraluminal fundoplication: a NOTES technique
}

\author{
Silvana Perretta • Bernard Dallemagne • \\ Pierre Allemann · Jacques Marescaux
}

Published online: 25 September 2010

(C) Springer Science+Business Media, LLC 2010

Erratum to: Surg Endosc

DOI 10.1007/s00464-010-1073-3

The correct spelling of the third author's name is Pierre Allemann.

The online version of the original article can be found under doi:10.1007/s00464-010-1073-3.

S. Perretta $(\bowtie) \cdot$ B. Dallemagne - P. Allemann · J. Marescaux Department of Gastrointestinal and Endocrine Surgery, IRCAD-EITS, University of Strasbourg, Strasbourg, France e-mail: Silvana.perretta@ircad.fr 